\title{
ANTISIPASI BANK UNTUK MENGHINDARI KREDIT MACET YANG DITIMBULKAN OLEH KERUGIAN DEBITUR AKIBAT PENCEMARAN LINGKUNGAN
}

\author{
Oleh : Hj. Nina Herlina, S.H., M.H.*) \\ ninaherlina86@yahoo.co.id
}

\begin{abstract}
The financial and banking sector as part of a business entity is certainly inseparable from this, although it does not directly contribute to high environmental pollution because the level of energy use, waste disposal and other activities also tends to be lower than other sectors. However, maintaining environmental sustainability is one of the responsibilities of the financial and banking sector, which is also required to constantly control and manage the environmental impacts resulting from the implementation of its business activities.

The cause of the problematic credit itself can be caused by internal and external factors. Internal factors are caused, among other things, by poor credit policies, weaknesses in the credit appraisal system and procedures, credit granting and supervision that deviate from procedures, bad intentions from bank owners, management and employees. While external factors, among others, are caused by the debtor's business environment, disasters or business failures, unhealthy interbank competition. In addition, in the credit analysis, it is necessary to anticipate banks to avoid bad credit caused by debtor losses due to environmental pollution.
\end{abstract}

Keywords: Anticipation, Bad Credit, Environmental Pollution

\section{ABSTRAK}

Sektor keuangan dan perbankan sebagai bagian dari entitas bisnis tentunya tidak terlepas dari hal ini, walaupun memang tidak secara langsung menyumbang pencemaran lingkungan yang tinggi karena tingkat penggunaan energi, pembuangan limbah, dan kegiatan lainnya pun cenderung lebih rendah dibanding sektor lainnya. Bagaimanpun juga, memelihara kelestarian lingkungan hidup merupakan salah satu bentuk tanggung jawab sektor keuangan dan perbankan, yang juga dituntut untuk senantiasa mengontrol dan mengelola dampak lingkungan yang dihasilkan dari pelaksanaan kegiatan bisnisnya.

Penyebab timbulnya kredit bermasalah sendiri dapat disebabkan faktor internal dan eksternal. Faktor Internal antara lain disebabkan oleh kebijakan perkreditan yang kurang menunjang, kelemahan sistem dan prosedur penilaian kredit, pemberian dan pengawasan kredit yang menyimpang dari prosedur, itikad yang kurang baik dari pemilik, pengurus, dan pegawai bank. Sedangkan faktor eksternal antara lain disebabkan oleh lingkungan usaha debitor, musibah atau kegagalan usaha, persaingan antar bank yang tidak sehat. Selain itu dalam analisis kredit diperlukan adanya antisipasi bank untuk menghindari kredit macet yang ditimbulkan oleh kerugian debitur akibat pencemaran lingkungan.

Kata Kunci : Antisipasi, Kredit Macet,Pencemaran Lingkungan

*) Dosen Tetap Fakultas Hukum Universitas Galuh 


\section{PENDAHULUAN}

Bank merupakan lembaga keuangan dan merupakan kekuatan ekonomi yang bekerja berdasarkan kepercayaan, dalam kegiatan operasionalnya bank menghimpun dana dari masyarakat dalam bentuk simpanan dan menyalurkan kembali dana tersebut kepada masyarakat dalam bentuk kredit (Sutojo,2000:5).

Pemberikan kredit oleh pihak bank harus memperhatikan asas-asas pemberian kredit yang sehat. Untuk memperoleh kenyakinan tersebut, seperti tersebut dalam penjelasan Pasal 8 Undang-undang Nomor 10 Tahun 1998 tentang perbankan yaitu dalam memberkan kredit, bank wajib melakukan penelitian yang seksama terhadap watak (character), kemampuan (capacity), modal (capita), agunan (collatera), kondisi ekonomi debitur (condition of economy). Hal ini untuk menjaga kemungkinan-kemungkinan yang tidak diharapkan terjadi (Siswanto, 1995:23).

Kredit macet terjadi jika pihak bank mengalami kesulitan untuk meminta angsuran dari pihak debitur karena suatu hal. Kredit macet adalah piutang yang tak tertagih atau kredit yang mempunyai kriteria kurang lancar, diragukan karena mengalami kesulitan pelunasan akibat adanya faktor-faktor tertentu (Lukman,2001:19). Seandainya terjadi hal yang demikian maka pihak bank tidak boleh begitu saja memaksakan pada debitur untuk segera melunasi hutangnya. Debitur berkewajiban untuk mengembalikan kredit yang telah diterimanya berikut dengan bunga sesuai yang tercantum dalam perjanjian.

Debitur yang sengaja tidak melunasi hutangnya maupun tidak menepati batas waktu pengembalian hutang, maka jaminan dapat digunakan untuk mengganti hutang. Jaminan kredit harus ada pada setiap pemberian kredit oleh bank. Hutang yang tidak terbayar oleh debitur akan menyebabkan kredit macet. Oleh karena Bank selain berkewajiban melaksanakan 5C dalam pemberian kredit tetapi harus melakukan antisipasi bank untuk menghindari kredit macet yang ditimbulkan oleh kerugian debitur akibat pencemaran lingkungan.

Penelitian ini bertujuan untuk mengetahui bagaimana antisipasi bank untuk menghindari kredit macet yang ditimbulkan oleh kerugian debitur akibat pencemaran lingkungan.

Adapun kegunaanya secara teoritis dapat memberikan manfaat bagi perkembangan ilmu pengetahuan khususnya Hukum Perbankan dan bidang lainnya yaitu Hukum Lingkungan. 
Metode penelitian yang digunakan yaitu yuridis normative dan komparatif yaitu yang menitikberatkan pada penelitian kepustakaan (data sekunder). Adapun caranya yaitu menelaah dan menganalisis berbagai peraturan perundang-undangan setelah terlebih dahulu menginventariasasi dan menemukan asas-asas hukum serta menemukan hukum (inconcreto) yang berkaitan dengan permasalahan dan hasilnya dipaparkan secara deskriptif analisis.

\section{TINJAUAN PUSTAKA}

\subsection{Pengertian dan Fungsi Bank}

Menurut Pasal 1 angka 2 Undang-Undang Republik Indonesia Nomor 10 Tahun 1998 Tentang Perubahan Atas Republik Indonesia Undang-Undang Nomor 7 tahun 1992 Tentang Perbankan, pengertian bank adalah badan usaha yang menghimpun dana dari masyarakat dalam bentuk simpanan dan menyalurkannya kepada masyarakat dalam bentuk kredit dan/atau bentuk-bentuk lainnya dalam rangka meningkatkan taraf hidup rakyat banyak.

Kasmir (2008: 11) mengartikan bank secara sederhana sebagai lembaga keuangan yang kegiatan utamanya adalah menghimpun dana dari masyarakat dan menyalurkan kembali dana tersebut kepada masyarakat serta memberiakn jasa bank lainnya.

Berdasarkan definisi tersebut, dapat di jelaskan secara lebih luas bahwa bank merupakan perusahaan atau lembaga yang bergerak dalam bidang keuangan, artinya aktivitas perbankan selalu berkaitan dengan keuangan, sedangkan dapat usaha perbankan meliputi tiga kegiatan utama, yaitu menghimpun dana dari masyarakat yang berkelebihan dana, menyalurkan dana kepada masyarakat yang membutuhkan, serta memberikan jasa di dalam lalu lintas pembayaran dan peredaran uang.

Secara umum, fungsi utama bank adalah menghimpun dana dari masyarakat luas (funding) dan menyalurkan kepada masyarakat dalam bentuk pinjaman atau kredit (lending) untuk berbagai tujuan.

Menurut Susilo, Triandanu Sigit \& A. Totok Budi Santoso, (2006:6) fungsi bank dijelaskan lebih spesifik yaitu antara lain : 


\section{Agent of Trust}

Trust atau kepercayaan adalah dasar utama dalam kegiatan perbankan, baik dalam hal menghimpun maupun penyaluran dana. Masyarakat akan menitipkan dananya di bank apabila dilandasi oleh unsur kepercayaan. Masyarakat percaya bahwa uangnya tidak akan disalahgunakan oleh bank, uangnya akan dikelola dengan baik, bank tidak akan bangkrut, dan pada saat yang dijanjikan masyarakat dapat menarik lagi simpanan di bank. Pihak bank sendiri akan mau menempatkan atau menyalurkan dana pada debitur atau masyarakat apabila dilandasi unsur kepercayaan. Pihak bank percaya bahwa debitur tidak akan menyalahgunakan pinjamannya, debitur akan mengelola dana pinjaman dengan baik, debitur akan mempunyai kemampuan membayar pada saat jatuh tempo, dan juga bank percaya bahwa debitur mempunyai niat baik untuk mengembalikan pinjaman beserta kewajiban lainnya pada saat jatuh tempo.

\section{Agent of Development}

Dalam kegiatan perekonomian masyarakat terdapat dua sektor, yaitu sektor moneter dam sektor riil yang tidak dapat dipisahkan dan saling mempengaruhi satu dengan yang lain. Sektor riil tidak akan dapat berkinerja dengan baik apabila sektor moneter tidak bekerja dengan baik pula. Tugas bank sebagai penghimpun dan penyalur dana sangat diperlukan untuk kelancaran kegiatan perekonomian di sektor riil. Kegiatan bank tersebut memungkinkan masyarakat melakukan investasi.

\section{Agent of Service}

Bank memberikan penawaran jasa-jasa antara lain dapat berupa jasa pengiriman uang, jasa penitipan barang berharga, jasa pemberian jaminan bank, dan jasa penyelesaian tagihan. Jasa-jasa bank tersebut erat kaitannya dengan kegiatan perekonomian masyarakat pada umumnya.

\subsection{Pengertian Kredit}

Istilah kredit berasal dari bahasa latin "credere" yang berarti kepercayaan. Dapat dikatakan dalam hubungan ini bahwa kreditur atau 
pihak yang memberikan kredit (bank) dalam hubungan perkreditan dengan debitur (nasabah penerima kredit) mempunyai kepercayaan bahwa debitur dalam waktu dan dengan syarat-syarat yang telah disetujui bersama dapat mengembalikan kredit yang bersangkutan

Menurut Pasal 1 angka 11 Undang-Undang Republik Indonesia Nomor 10 Tahun 1998 Tentang Perubahan Atas Undang-Undang Republik Indonesia Nomor 7 tahun 1992 Tentang Perbankan, merumuskan pengertian kredit adalah "Penyediaan uang atau tagihan yang dapat dipersamakan dengan itu, berdasarkan persetujuan atau kesepakatan pinjam meminjam antara bank dengan pihak lain yang mewajibkan pihak peminjam melunasi hutangnya setelah jangka waktu tertentu dengan pemberian bunga".

Dari uraian diatas, kredit mengandung unsur-unsur sebagai berikut :

1. Kepercayaan yaitu keyakinan dari si pemberi kredit bahwa prestasi yang diberikan baik dalam bentuk uang, barang atau jasa, akan benarbenar diterimanya kembali dalam jangka waktu tertentu dimasa yang akan datang.

2. Waktu suatu masa yang memisahkan antara pemberian prestasi dengan kontra prestasi yang akan diterima pada masa yang akan datang. Dalam arti nilai agio dari uang yaitu uang yang ada sekarang lebih tinggi nilainya dari uang yang akan diterima pada masa yang akan datang.

3. Degree of risk yaitu suatu tingkat resiko yang akan dihadapi sebagai akibat dari adanya jangka waktu yang memisahkan antara pemberian prestasi dengan kontraprestasi yang akan diterima dikemudian hari. Semakin lama kredit diberikan semakin tinggi tingkat resikonya, karena sejauh kemampuan manusia untuk menerobos hari depan itu, maka hasil selalu terdapat unsur ketidaktentuan yang tidak dapat diperhitungkan, yang menyebabkan timbul jaminan dalam pemberian kredit.

4. Prestasi atau objek kredit itu tidak saja diberikan dalam bentuk uang, tetapi dapat juga dalam bentuk barang atau jasa namun sekarang ini 
didasarkan kepada uang, maka transaksi-transaksi kredit yang menyangkut uang yang sering dijumpai dalam praktek perkreditan.

Dari pengertian kredit diatas tampak bahwa dasar utama dalam pemberian kredit adalah kepercayaan yang dilandasi kesepakatan untuk memberikan pinjaman sejumlah uang dengan pemberian bunga. Peluncuran kredit oleh suatu bank mestilah dilakukan dengan berpegangan pada beberapa prinsip, yaitu sebagai berikut :

1. Prinsip kepercayaan.

Sesuai dengan asal kata kredit yang berarti kepercayaan, maka setiap pemberian kredit sebenarnya mestilah selalu dibarengi oleh kepercayaan. Yakni kepercayaann dari kreditur akan bermanfaatnya kredit bagi debitur sekaigus kepercayaan oleh kreditur bahwa debitur dapat membayar kembali kreditnya. Tentunya untuk bisa memenuhi unsur kepercayaan ini oleh kreditur mestilah dilihat apakah calon debitur memenuhi berbagai kriteria yang biasanya diberlakukan terhadap pemberian suatu kredit. Karena itu timbul prinnsip lain yang disebut prinsip kehati-hatian.

2. Prinsip kehati-hatian.

Prinsip kehati-hatian (prudent) ini adalah salah satu konkretisasi dari prinsip kepercayaan dalam suatu pemberian kredit. Disamping pula sebagai perwujudan dari prinsip prudent banking dari seluruh kegiatan perbankan. Untuk mewujudkan prinsip kehati-hatian dalam pemberian kredit ini, maka berbagai usaha pengawasan dilakukan, baik oleh bank itu sendiri (internal) maupun oleh pihak luar (external), in casu oleh pihak Bank Sentral. Demikian juga dengan keharusan adanya jaminan hutang dalam setiap pemberian kredit sebenarnya juga mempunyai tujuan agar kredit diluncurkan secara hati-hati, sehingga ada jaminan bahwa kredit yang bersangkutan aka dibayar kembali oleh pihak debitur.

3. Prinsip 5C.

Prinsip 5C adalah singkatan dari unsur-unsur Character, Capacity, Capital, Conditions of Economy, dan Collateral. Untuk ini akan kita tinjau satu persatu dari unsur tersebut yang seyogianya selalu ada dalam setiap pemberian kredit. 
a) Character (Kepribadian), salah satu unsur yang mesti diperhatikan oleh bank sebelum memberikan kreditnya adalah penilaian atas karakter kepribadian/watak dari calon debiturnya. Karena watak yang jelek akan menimbulkan perilaku-perilaku yang jelek pula.

b) Capacity (kemampuan), seorang calon debitur harus pula diketahui kemampuan bisnisnya, sehingga dapat diprediksi kemampuannya untuk melunasi hutangnya.

c) Capital (Modal), permodalan dari suatu debitur juga merupakan hal yang penting harus diketahui oleh calon krediturnya. Karena permodalan dan kemampuan keuangan dari suatu debitur akan mempunyai korelasi langsung dengan tingkat kemampuan bayar kredit. Jadi masalah likuiditas dan solvabilitas dari suatu badan usaha menjadi penting artinya.

d) Condition of Economy (Kondisi Ekonomi), kondisi perekonomian secara mikro maupun makro merupakan faktor penting pula untuk dianalisis sebelum suatu kredit diberikan, terutama yang berhubungan langsung dengan bisnisnya pihak debitur.

e) Collateral (Agunan), tidak diragukan lagi bahwa betapa pentingnya fungsi agunan dalam setiap pemberian kredit.

4. Prinsip 5P.

Dalam suatu pemberian kredit oleh bank, selain prinsip $5 \mathrm{C}$ juga terdapat apa yang dinamakan prinsip 5P, yang merupakan singkatan dari Party, Purpose, Payment, Profitability, dan Protection. Untuk ini akan ditinjau satu persatu dari prinsip tersebut.

a) Party (Para Pihak)

Para pihak merupakan titik sentral yang memperhatikan dalam setiap pemberian kredit. Untuk itu pihak pemberi kredit harus memperoleh suatu "kepecayaan" terhadap para pihak, dalam hal ini debitur. Bagaimana karakternya, kemampuannya, dan sebagainya.

b) Purpose (Tujuan)

Tujuan dari pemberian kredit juga sangat penting diketahui oleh pihak kreditur. Harus dilihat apakah kredit akan digunakan untuk hal-hal yang positif yang benar-benar dapat menaikkan income perusahaan. Dan harus pula diawasi agar kredit tersebut 
benar-benar diperuntukkan untuk tujuan seperti diperjanjikan dalam suatu perjanjian kredit.

c) Payment (Pembayaran)

Harus pula diperhatikan apakah sumber pembayaran kredit dari calon debitur cukup tersedia dan cukup aman, sehingga dengan demikian diharapkan bahwa kredit yang akan diluncurkan tersebut dapat dibayar kembali oleh debitur yang bersangkutan. Jadi harus dilihat dan dianalisis apakah setelah pemberian kredit nanti debitur punya sumber pendapatan, dan apakah pendapatan tersebut mencukupi untuk membayar kembali kreditnya.

d) Profitability (Perolehan Laba)

Unsur perolehan laba oleh debitur tidak kurang pula pentingnya dalam suatu pemberian kredit. Untuk itu kreditur harus dapat berantisipasi, apakah laba yang akan diperoleh oleh perusahaan lebih besar dari bunga pinjaman dan apakah pendapatan perusahaan dapat menutupi pembayaran kembali kredit, cash flow, dan sebagainya.

e) Protection (Perlindungan)

Diperlukan suatu perlindungan terhadap kredit oleh perusahaan debitur. Untuk itu perlindungan dari kelompok perusahaan atau jaminan dari holding atau jaminan pribadi pemilik perusahaan penting diperhatikan. Terutama untuk berjaga-jaga sekiranya terjadi hal-hal di luar yang diskenariokan atau di luar prediksi semula.

5. Prinsip 3R.

Prinsip 3R, yang merupakan singkatan dari Returns, Repayment, dan Risk Bearing Ability. Untuk ini juga akan ditinjau satu persatu.

a) Returns (Hasil yang Diperoleh)

Yakni yang merupakan hasil yang akan diperoleh oleh debitur, dalam hal ini ketika kredit telah dimanfaatkan nanti mestilah dapat diantisipasi oleh calon kreditur. Artinya perolehan tersebut mencukupi untuk membayar kembali kredit beserta bunga, ongkosongkos, disamping membayar keperluan perusahaan yang lain seperti untuk cash flow, kredit lain jika ada, dan sebagainya. 
b) Repayment (Pembayaran Kembali)

Kemampuan membayar dari pihak debitur tentu saja harus dipertimbangkan. Dan apakan kemampuan bayar tersebut macth dengan schedule pembayaran kembali dari kredit yang akan diberikan itu. Ini juga merupakan hal yang tidak boleh diabaikan.

c) Risk Bearing Ability (Kemampuan Menganggung Risiko)

Hal lain yang perlu diperhatikan juga adalah sejauhmana terdapatnya kemampuann debitur unntuk menanggung risiko. Misalnya dalam hal-hal di luar antisipasi kedua belah pihak. Terutama jika dapat menyebabkan timbulnya kredit macet. Untuk itu harus diperhitungkan apakah misalnya jaminan dan/atau asuransi barang atau kredit sudah cukup aman untuk menutupi risiko tersebut.

\subsection{Pengertian Kredit Macet}

Kredit macet dapat diartikan sebagai pinjaman yang mengalami kesulitan pelunasan akibat adanya faktor kesengajaan dan atau karena faktor eksternal diluar kemampuan kendali debitur (Dahlan, 2001:174). Sedangkan menurut Veithzal Riva"i (2008:477) kredit macet merupakan kesulitan nasabah di dalam penyelesaian kewajiban-kewajibannya terhadap bank,baik dalam bentuk pembayaran kembali pokoknya, pembayaran bunga, maupun pembayaran ongkos-ongkos bank yang menjadi beban nasabah debitur yang bersangkutan.

Berdasarkan pengertian tersebut dapat disimpulkan bahwa kredit macet sebagai pinjaman yang mengalami kesulitan dalam penyelesaian kewajiban-kewajibannya oleh nasabah debitur terhadap bank karena faktor kesengajaan dan atau karena faktor eksternal diluar kemampuan kendali debitur.

Faktor-faktor penyebab kredit macet menurut Dahlan (2001: 175) disebabkan oleh berbagai faktor, antara lain:

1. Faktor Internal

Faktor internal kredit bermasalah ini berhubungan dengan kebijakan strategi yang ditempuh oleh pihak bank, antara lain :

a. Kebijakan perkreditan yang ekspansif

b. Penyimpangan dalam pelaksanaan prosedur perkreditan 
c. Lemahnya sistem administrasi dan pengawasan kredit

d. Lemahnya sistem informasi kredit

e. Itikad kurang baik dari pihak bank

2. Faktor Eksternal

a. Penurunan kegiatan ekonomi dan tingginya tingkat bunga kredit

b. Pemanfaatan iklim persaingan perbankan yang tidak sehat oleh debitur

c. Kegagalan usaha debitur

d. Debitur mengalami musibah

Menurut Lukman (2001:38) faktor-faktor yang menyebabkan kredit macet adalah :

1. Kelemahan bank dalam melakukan analisis, sehingga terjadi kesalahan dalam pengambilan keputusan.

2. Kelemahan nasabah

a. Perencanaan.

Perencanaan adalah gambaran sebelum sesuatu dilaksanakan. Untuk memulai usaha tentunya harus ada rencana tentang pinjaman yang diambil untuk memperlancar usaha atau memulai usaha agar usaha dapat berjalan dengan baik. Tanpa adanya perencanaan maka pinjaman yang diperoleh tidak akan dapat dimanfaatkan untuk menjalankan usaha secara lancar dan tidak terarah pada pencapaian tujuan usaha

b. Pendapatan yang relatif rendah

Jika pendapatan yang diperoleh relatif rendah, nasabah sulit untuk mengembalikan pinjaman, karena pendapatan yang diperoleh hanya cukup untuk memenuhi kebutuhan seharihari.

c. Administrasi

Administrasi merupakan pengaturan suatu kegiatan secara teratur. Berjalannya usaha harus dapat diatur administrasinya dan dikendalikan tentang pemasukan dan pengeluaran keuangan agar jalannya usaha dapat diatur.

3. Kenakalan nasabah

a. Pengambilan kredit diharapkan dapat digunakan sepenuhnya untuk menambah modal, tetapi belum tentu hal itu dilakukan semua para pengusaha karena ada yang menggunakan pinjaman tersebut untuk keperluan sehari-hari atau melunasi hutang pada pihak lain sehingga pinjaman tersebut tidak optimal penggunaannya.

b. Itikad nasabah adalah niat atau keinginan untuk membayar pinjaman yang ada pada diri responden.

4. Bencana Alam

5. Peperangan

6. Perubahan kondisi perekonomian

7. Perubahan teknologi 


\subsection{Pengertian Pencemaran}

Berdasarkan Pasal 1 Butir 14 Undang-Undang Republik Indonesia Nomor 32 Tahun 2009 disebutkan, yang dimaksud dengan pencemaran lingkungan hidup adalah masuk atau dimasukannya mahluk hidup, zat, energi dan/atau komponen lain ke dalam lingkungan oleh kegiatan manusia sehingga melampaui baku mutu lingkungan hidup yang telah ditetapkan.

Apabila dilihat dari segi ilmiah, suatu lingkungan dapat disebut sudah tercemar bila memiliki beberapa unsur. Unsur-unsur tersebut adalah :

1. Kalau suatu zat, organisme, atau unsur-unsur yang lain (seperti gas, cahaya, energi) telah tercampur (terintroduksi) ke dalam sumber daya/lingkungan tertentu;

2. Karenanya menghalang/menggangu ke dalam sumber daya/lingkungan tersebut (N.H.T Siahaan, 2004:280).

Apabila disimpulkan maka pencemaran adalah suatu keadaaan yang terjadi karena perubahaan kondisi tata lingkungan (tanah, udara dan air) yang tidak menguntungkan (merusak dan merugikan kehidupan manusia, binatang dan tumbuhan) yang disebabkan oleh kehadiran benda-benda asing (seperti sampah kota, sampah industri, minyak bumi, sisa-sisa biosida dan sebagainya) sebagai akibat perbuatan manusia, sehingga mengakibatkan lingkungan itu tidak berfungsi seperti semula (Y.Eko Budi Susilo, 2003 : 9).

Apabila dalam pemberian kredit kepada usaha yang akan menimbulkan daampak besar dan penting, maka Bank harus memeriksa ada tidaknya dokumen AMDAL, sebagaimana dijelaskan dalam pasal Pasal 22 Undang-Undang Republik Indonesia Nomor 32 Tahun 2009 Tentang Perlindungan dan Pengelolaan Lingkungan Hidup menetapkan bahwa :

(1) Setiap rencana usaha dan/atau kegiatan yang berdampak penting terhadap lingkungan wajib memiliki Amdal.

(2) Dampak penting ditentukan berdasarkan criteria ;

a. besarnya jumlah penduduk yang akan terkena dampak rencana usaha dan/atau kegiatan ;

b. luas wilayah penyebaran dampak ;

c. intensitas dan lamanya dampak berlangsung ; 
d. banyaknya komponen lingkungan hidup lain yang akan terkena dampak ;

e. sifat kumulatif dampak ;

f. berbalik atau tidak berbaliknya dampak; dan/atau

g. kriteria lain sesuai dengan perkembangan ilmu pengetahuan dan teknologi.

Adanya dokumen AMDAL, Bank mampu menganalisis suatu kerugian yang akan timbul dari kegiatan usaha debitur sehingga akan memperkecil tingkat kerugian Bank. Selain itu diperlukan juga pemeriksaan terhadap dilaksanakan atau tidaknya perlindungan berupa asuransi oleh debitur terhadap usaha yang dijalankannya.

Disisi lain Bank merupakan lembaga yang berbadan hukum, sesuai ketentuan Pasal 68 huruf b Undang-Undang Republik Indonesia Nomor 32 Tahun 2009 tentang Perlindungan dan Pengelolaan Lingkungan Hidup, yaitu bahwa setiap orang yang melakukan usaha dan/atau kegiatan berkewajiban menjaga keberlanjutan fungsi lingkungan hidup. Bunyi Pasal tersebut maka Badan Hukum seperti Bank juga ditafsirkan sebagai orang, oleh karena itu mempunyai kewajiban menjaga keberlanjutan fungsi lingkungan hidup. Sehubungan hal tersebut sektor keuangan dan perbankan sebagai bagian dari entitas bisnis tentunya tidak terlepas dari hal ini, walaupun memang tidak secara langsung menyumbang pencemaran lingkungan yang tinggi karena tingkat penggunaan energi, pembuangan limbah, dan kegiatan lainnya pun cenderung lebih rendah dibanding sektor lainnya. Bagaimanpun juga, memelihara kelestarian lingkungan hidup merupakan salah satu bentuk tanggung jawab sektor keuangan dan perbankan, yang juga dituntut untuk senantiasa mengontrol dan mengelola dampak lingkungan yang dihasilkan dari pelaksanaan kegiatan bisnisnya.

\section{HASIL PENELITIAN DAN PEMBAHASAN}

Berbagai lembaga keuangan, terutama bank telah membantu pemenuhan kebutuhan dana bagi kegiatan perekonomian dengan memberikan pinjaman uang antara lain dalam bentuk Kredit Perbankan. Kredit Perbankan merupakan salah satu usaha bank yang telah banyak dimanfaatkan oleh anggota masyarakat yang memerlukan dana. Perbankan Indonesia bertujuan 
menunjang pelaksanaan pembangunan nasional dalam rangka meningkatkan pemerataan, pertumbuhan ekonomi, dan stabilitas nasional kearah peningkatan kesejahteraan rakyat banyak.

Peranan bank sangat penting selaku lembaga keuangan dengan tugas pokok yaitu menghimpun dana dari masyarakat dan menyalurkannya kembali kepada masyarakat, pengusaha (entrepreneur) untuk membiayai sektor riil melalui pemberian kredit.

Menurut Pasal 1 angka 11 Undang-Undang Republik Indonesia Nomor 10 Tahun 1998 Tentang Perubahan Atas Undang-Undang Republik Indonesia Nomor 7 tahun 1992 Tentang Perbankan, merumuskan pengertian kredit adalah "Penyediaan uang atau tagihan yang dapat dipersamakan dengan itu, berdasarkan persetujuan atau kesepakatan pinjam meminjam antara bank dengan pihak lain yang mewajibkan pihak peminjam melunasi hutangnya setelah jangka waktu tertentu dengan pemberian bunga".

Melalui pemberian kredit kepada pengusaha kecil dan menengah ini diharapkan usaha mereka semakin maju sehingga perekonomian masyarakat di lingkungan pedesaan dapat ditingkatkan.

Bisnis perkreditan yang dilakukan oleh bank merupakan bisnis yang mengandung resiko. Kegiatan perkreditan merupakan proses pembentukan asset bank. Kredit merupakan risk asset bagi pihak bank karena asset bank itu dikuasai pihak luar bank yaitu para debitur. Oleh karena itu kredit harus didasarkan pada asas-asas perkreditan yang sehat. Untuk mengurangi resiko tersebut bank wajib memiliki keyakinan terhadap kemampuan debitur untuk melunasi hutang-hutangnya.

Menurut Undang-Undang Republik Indonesia Nomor 10 Tahun 1998 Tentang Perubahan Atas Undang-Undang Republik Indonesia Nomor 7 tahun 1992 Tentang Perbankan bahwa dalam memberikan kredit bank wajib mempunyai keyakinan berdasarkan analisis yang mendalam atas itikad baik dan kemampuan debitur serta kesanggupan nasabah debitur untuk melunasi utangnya atau mengembalikan hutang dimaksud sesuai dengan yang diperjanjikan.

Pedoman analisis kredit yang paling sering digunakan di dunia perbankan adalah analisis dengan menggunakan penilaian dari segi $5 \mathrm{C}$ yaitu : 
a) Character (Kepribadian), salah satu unsur yang mesti diperhatikan oleh bank sebelum memberikan kreditnya adalah penilaian atas karakter kepribadian/watak dari calon debiturnya. Karena watak yang jelek akan menimbulkan perilaku-perilaku yang jelek pula.

b) Capacity (kemampuan), seorang calon debitur harus pula diketahui kemampuan bisnisnya, sehingga dapat diprediksi kemampuannya untuk melunasi hutangnya.

c) Capital (Modal), permodalan dari suatu debitur juga merupakan hal yang penting harus diketahui oleh calon krediturnya. Karena permodalan dan kemampuan keuangan dari suatu debitur akan mempunyai korelasi langsung dengan tingkat kemampuan bayar kredit. Jadi masalah likuiditas dan solvabilitas dari suatu badan usaha menjadi penting artinya.

d) Condition of Economy (Kondisi Ekonomi), kondisi perekonomian secara mikro maupun makro merupakan faktor penting pula untuk dianalisis sebelum suatu kredit diberikan, terutama yang berhubungan langsung dengan bisnisnya pihak debitur.

e) Collateral (Agunan), tidak diragukan lagi bahwa betapa pentingnya fungsi agunan dalam setiap pemberian kredit.

Analisis kredit yang dilakukan sebelum kredit diberikan sangat penting untuk mencegah terjadinya kredit bermasalah di kemudian hari. Setiap perjanjian kredit yang dilakukan di bank selalu diikuti dengan perjanjian jaminan. Perjanjian jaminan ini bersifat accessoir artinya keberadaannya tergantung dan mengikuti perjanjian pokoknya. Dengan demikian kepentingan bank sebagai kreditur dapat terlindungi. Jaminan tersebut memiliki beberapa kelemahan karena berlaku untuk semua kredit, terhadap keseluruhan harta debitur sehingga apabila terdapat banyak kreditur dimungkinkan ada beberapa kreditur yang tidak mendapatkan kembalian pelunasan piutangnya. Dengan adanya kelemahan tersebut para kreditur seringkali meminta jaminan khusus kepada debitur sebagai jaminan untuk pelunasan kredit yang telah diberikan kepadanya. Fungsi jaminan kredit adalah dapat digunakan jaminan kewajiban debitur yang tidak dapat dipenuhi. Namun dalam pelaksanaan kredit dengan jaminan dalam prakteknya kadangkala tidak dilaksanakan sebagaimana mestinya. Kadangkala terjadi permasalahan seperti debitur yang wanprestasi baik berupa keterlambatan pembayaran maupun ketidakmampuan debitur 
dalam melunasi hutang-hutangnya. Ketidakmampuan debitur untuk melunasi hutang-hutangnya menjadikan kualitas kredit yang diberikan menjadi kredit yang bermasalah. Adanya kredit bermasalah perlu segera diatasi oleh pihak bank karena dapat berpengaruh terhadap tingkat kesehatan bank tersebut.

Bank dalam setiap melaksanakan perjanjian kredit selaku kreditor percaya bahwa setiap debitor memiliki kemampuan memenuhi kewajibannya untuk melunasi segala hutang yang telah disepakati antara bank dengan debitor. Akan tetapi, dalam kenyataannya tidak seperti yang diharapkan sebelumnya. Berbagai macam faktor di luar perhitungan atau jangkauan perkiraan dapat terjadi, sekalipun telah dilakukan analisis mendalam dan penuh kehati-hatian melalui verifikasi dan analisis kredit yang baik.

Penyebab timbulnya kredit bermasalah sendiri dapat disebabkan faktor internal dan eksternal. Faktor Internal antara lain disebabkan oleh kebijakan perkreditan yang kurang menunjang, kelemahan sistem dan prosedur penilaian kredit, pemberian dan pengawasan kredit yang menyimpang dari prosedur, itikad yang kurang baik dari pemilik, pengurus, dan pegawai bank. Sedangkan faktor eksternal antara lain disebabkan oleh lingkungan usaha debitor, musibah atau kegagalan usaha, persaingan antar bank yang tidak sehat

Hal lain yang tidak kalah pentingnya dalam analisis kredit adalah antisipasi bank untuk menghindari kredit macet yang ditimbulkan oleh kerugian debitur akibat pencemaran lingkungan.

Pencemaran lingkungan menurut Pasal 1 Butir 14 Undang-Undang Republik Indonesia Nomor 32 Tahun 2009 disebutkan, yang dimaksud dengan pencemaran lingkungan hidup adalah masuk atau dimasukannya mahluk hidup, zat, energi dan/atau komponen lain ke dalam lingkungan oleh kegiatan manusia sehingga melampaui baku mutu lingkungan hidup yang telah ditetapkan.

Bank disamping harus menerapkan prinsip $5 \mathrm{C}$ dalam pemberian kredit dan melakukan pemeriksaan terhadap adanya dokumen yang harus dimilki seperti AMDAL, sehingga Bank mampu menganalisis suatu kerugian yang akan timbul dari kegiatan usaha debitur sehingga akan memperkecil tingkat kerugian Bank. Selain itu diperlukan juga pemeriksaan terhadap dilaksanakan atau tidaknya perlindungan berupa asuransi oleh debitur terhadap usaha yang dijalankannya dan menganalisis benda-benda yang dijaminkan debitur tidak akan mencemari lingkungan, karena apabila jaminan tersebut berupa tanah dan 
tanah tersebut tercemar limbah B3, maka jaminan tersebut bisa tidak mempunyai nilai lagi. Begitu juga usaha debitur jangan sampai kegiatan usahanya dapat menimbulkan pencemaran kerena membuang limbah yang mengakibatkan pencemaran lingkungan yang mengakibatkan izin usahamya dicabut oleh Pemerintah. Dengan dicabutnya izin usaha tersebut mengakibatkan debitur tidak dapat menjalankan usahanya sehingga tidak dapat melaksanakan kewajibannya, hal tersebut dapat menimbulkan kerugian bank karena terjadinya kredit macet.

\section{KESIMPULAN}

Dalam pemberian kredit Bank harus berpedoman pada prinsip $5 \mathrm{C}$, disamping itu adanya pemeriksaan ada tidaknya dokumen AMDAL yang dimiliki oleh pengusaha sehingga Bank mampu menganalisis suatu kerugian yang akan timbul dari kegiatan usaha debitur dan akan memperkecil tingkat kerugian Bank. Selain itu diperlukan juga pemeriksaan terhadap dilaksanakan atau tidaknya perlindungan berupa asuransi oleh debitur terhadap usaha yang dijalankannya. Selanjunya Bank harus melakukan antisipasi terhadap potensi pencemaran kegiatan usaha calon debitur atau debitur setidak-tidaknya karena tiga hal, yaitu sebagai pemegang jaminan kredit ikut serta dalam managemen dan demi keamanan dan kelancaran pembayaran kredit itu sendiri, Bank sebagai kreditur dalam hubungannya dengan perjanjian kredit memegang jaminan atas pinjaman yang diberikannya, apabila jaminan tersebut berupa tanah dan tanah tersebut tercemar limbah berbahaya dan beracun (B3), maka jaminan tersebut tidak mempunyai nilai lagi.

Selain itu bank akan menderita kerugian dengan adanya kredit macet yang diakibatkan berhentinya kegiatan debitur karena sanksi yang dijatuhkan Pemerintah berupa pencabutan izin usaha karena debitur membuang limbah sisa hasil usahanya tanpa dinetralisir terlebih dahulu oleh alat pengendali pencemaran sehingga menimbulkan pencemaran lingkungan. Oleh karena itu Bank dalam pemberian kredit kepada debitur tidak hanya ditentukan oleh faktor $5 \mathrm{C}$ tetapi harus melakukan antisipasi untuk menghindari kredit macet yang ditimbulkan oleh kerugian debitur akibat pencemaran lingkungan. 


\section{DAFTAR PUSTAKA}

\section{A. Buku-Buku}

Dahlan Siamat, 2001, Manajemen Lembaga Keuangan, Jakarta, Fakultas Ekonomi Universitas Indonesia.

Kasmir, 2008, Bank dan Lembaga Keuangan Lainnya, Edisi Revisi 2008, Jakarta, PT. Rajagrafindo Persada.

Lukman Dendawijaya, 2001, Manajemen Perbankan, Jakarta, PT Ghalia Indonesia.

N.H.T Siahaan, 2004, Hukum Lingkungan dan Ekologi Pembangunan, Jakarta, Erlangga.

Siswanto Sutojo,1995, Analisa Kredit Bank Umum, Jakarta, PT. Ikrar Mandiri Abad.

Susilo Sri Y., Sigit Triandaru, Totok Budi Santoso, 2006, Bank dan Lembaga Keuangan Lain, Jakarta, Salemba Empat.

Sutojo Siswanto, 2000, Strategi Manajemen Kredit Bank Umum Konsep, Teknik, dan Kasu, Jakarta, Damar Mulia Pustaka.

Veithzal Rivai, 2008, Performance Appraisal, Jakarta, PT. Raja Grafindo Persada.

Y.Eko Budi Susilo, 2003, Menuju Keselarasan Lingkungan (Memahami Sikap Teologis Manusia Terhadap Pencemaran Lingkungan), Malang, Averroes Press.

\section{B. Sumber Perundang-undangan :}

Undang-Undang Republik Indonesia Nomor 10 Tahun 1998 Tentang Perubahan Atas Undang-Undang Republik Indonesia Nomor 7 tahun 1992 Tentang Perbankan.

Undang-Undang Republik Indonesia Nomor 32 Tahun 2009 tentang Perlindungan dan Pengelolaan Lingkungan Hidup. 